\title{
The Ability of Geographic Teachers in Applying Authentic Assessment Through Online Learning
}

\author{
Irma Lusi Nugraheni \\ \{irmalusi42@gmail.com\}
}

Geography Education, FKIP University of Lampung, Bandar Lampung, Indonesia

\begin{abstract}
This study aims to determine the ability of geography teachers in high school to apply authentic assessment to class XI disaster mitigation materials. This study uses a quantitative approach. The parameters used to measure the teacher's ability in authentic assessment include 1) authentic assessment planning, 2) implementation of authentic assessment, 3) analysis of authentic assessment results. The sample in this study were geography teachers in Lampung Province from various districts who taught at public high schools in Lampung Province. The sampling technique uses area sampling technique. Data collection using a questionnaire. The research result shows that of 42 Geography teachers who are spread across several districts, their ability to carry out authentic assessments of online disaster mitigation materials is in a good category.
\end{abstract}

Keywords: Geography, Authentic Assessment, Mitigation.

\section{Introduction}

The focus of assessment in the 2013 curriculum is the success of student learning in achieving the specified competency standards, including attitudes, skills and knowledge. Students can be said to be competent after being assessed with instruments that are truly competent and relatively permanent, so that the information provided is truly accurate [1]. the assessment used based on the 2013 curriculum is authentic assessment. Permendikbud No. 104 of 2014 article 2 paragraph 2 states that authentic assessment is the main approach in assessing student learning outcomes by educators.

The assessment carried out includes the competence attitudes, skills and knowledge during the learning process. In authentic assessment, students are asked to apply a concept or theory in real terms according to their abilities or skills [1]. As a result of the Covid 19 Pandemic, Indonesia implemented Online Learning [2]. This condition is certainly experienced by all teachers in Indonesia. Online learning that is applied, apparently cannot be implemented optimally.

Teachers and students are still clueless about this learning model [3]. The problems faced by geography teachers during the COVID-19 pandemic, especially for authentic assessment, are the same thing faced by teachers in other fields of study, where teachers cannot directly monitor the learning carried out by students at home. For the assessment of attitude aspects, for example, the measurement of honesty, discipline, responsibility and so on, is only limited to being on time or not when submitting assignments, according to the deadline. Assessment of the spiritual aspect also cannot be maximized, because the teacher is not present in the midst of students praying to observe [4]. So far, what students do is send photos when they worship their teachers . But, it is also not accurate, that the students really worship 
setiapa day, so that online learning is sa Ngat difficult to measure aspects of honesty students. $\mathrm{T}$ duties as given dikumpukan sometimes not timely even some students who can not collect due to a weak Internet networks in the area where he lives. This condition certainly prevents teachers from immediately carrying out authentic assessments because they cannot immediately recap the value at that time. Not to mention being constrained by the internet network. If this is not done immediately, then at the end of the semester the teacher will be very difficult, because there are many grades that have to be added up.

In addition, the authentic assessment that has been carried out has not been maximized because the existing assessment techniques and instruments cannot be implemented in the learning process during the Covid 19 pandemic. The reason is because there is no instrument standard that is appropriate for the current conditions, so there are become teachers who use $\mathrm{i}$ nstrumen long time, there are also creative makes its instrument of accession itself.

\section{Method}

This study uses a single variable, namely the ability of teachers to apply authentic assessment in geography learning during online learning. The material used as the basis for the assessment is disaster mitigation material for class XI even semester. There are 3 indicators in this authentic assessment research, planning an authentic assessment, implementing an authentic assessment, analyzing the results of the assessment. Planning authentic assessment includes mene $\mathrm{n}$ tukan purpose and focus, planning contents authentic assessment that includes: the selection procedure of assessment, determine the content/topic and set the frequency da $n$ time to assess, $m$ endesain how to analyze data, namely by setting: standard or criteria, define how to integrate the assessment from various sources (eg from the performance, portfolio evaluation, test, etc) and set the time of analysis, planning measures assessment activities (integrated in learning, there are activities in providing feedback, process assessment and product assessment). Implementation of authentic assessment, announce covering purpose and focus of learning to learners, agreement assessment procedures used and the criteria of judgment, discuss ways that need to be done to achieve maximum results. Carry out assessment activities in accordance with the collective agreement planning (data collection).

Privide feedback. Analysis of the results of the assessment includes analyzing the data that has been collected, combining the results of the analysis from the various data obtained, applying the final assessment criteria and reporting the results of the assessment. The method used is descriptive quantitative. The population is a geography teacher who teaches online at public high schools in 13 districts of Lampung Province. Samples techniques are in use right is a sampling nonprobability use sampling area .

Table 1. Determination Of Samples Based On The Sampling Area

\begin{tabular}{llcccc}
\hline No & \multicolumn{1}{c}{ District } & $\begin{array}{c}\text { Population of } \\
\text { Senior High School }\end{array}$ & $\mathbf{1 0 \%}$ & $\begin{array}{c}\text { Sample } \\
\text { School }\end{array}$ & $\begin{array}{c}\text { Number of geography } \\
\text { teachers in 1 school }\end{array}$ \\
\hline 1 & Pringsewu & 10 & 1 & 1 & 2 \\
2 & Tanggamus & 15 & 1.5 & 2 & 4 \\
3 & South Lampung & 17 & 1.7 & 2 & 4 \\
4 & Pesisir Barat & 10 & 1 & 1 & 2 \\
5 & Pesawaran & 13 & 1.3 & 1 & 2 \\
6 & East Lampung & 19 & 1.9 & 2 & 4 \\
\hline 7 & Central Lampung & 24 & 2.4 & 2 & 4 \\
8 & Mesuji & 8 & 0.8 & 1 & 2
\end{tabular}




\begin{tabular}{clcccc}
9 & Tulang Bawang & 15 & 1.5 & 2 & 4 \\
10 & Tulang Bawang Barat & 14 & 1.4 & 1 & 2 \\
11 & Way Kanan & 26 & 2.6 & 3 & 6 \\
12 & West Lampung & 13 & 1.3 & 1 & 2 \\
13 & North Lampung & 18 & 1.8 & 2 & 4 \\
\hline$\quad$ Total & $\mathbf{2 0 2}$ & $\mathbf{2 0 . 2}$ & $\mathbf{2 1}$ & $\mathbf{4 2}$ \\
\hline
\end{tabular}

Obtained amount teacher who used a sample of 42 people. Options statement proposed in the questionnaire included 30 items item statement with alternative answers yes and tidak. Ya given a score of 1 and given a score of 0 . The maximum score of 30, the lowest score of 0 . Summary of the results of respondents wanted the average was calculated as follows: Average score $=$ total score/number of question items. Furthermore, it is determined in the form of a percentage with the following calculation:

$$
\text { Percentage Score }=\frac{\text { Average Score }}{\text { Ideal Score }} \times 100 \%
$$

Table 2. Categories Of Percentage

\begin{tabular}{lc}
\hline \multicolumn{1}{c}{ Category } & Percentage \\
\hline Well & $76 \%-100 \%$ \\
Enough & $56 \%-75 \%$ \\
Less good & $40 \%-55 \%$ \\
Not Good & $4 \%-40 \%$ \\
\hline
\end{tabular}

\section{Research Results}

The results of this study are used to describe how the authentic assessment of geography teachers in learning which contains disaster mitigation education material through an online learning process through aspects of planning, implementation and evaluation. The results of the study are shown in the tables below.

\subsection{Authentic Assessment Planning}

Table 3. Authentic Assessment Planning

\begin{tabular}{clccc}
\hline No & \multicolumn{1}{c}{ Sub Indicator } & Score & Percentage & Criteria \\
\hline 1 & $\begin{array}{l}\text { Make an integrated assessment plan referring to the } \\
\text { syllabus and lesson plans }\end{array}$ & 42 & 100 & Well \\
2 & $\begin{array}{l}\text { Develop criteria for achieving basic competencies as a } \\
\text { basis for assessment } \\
\text { Determine assessment techniques and instruments } \\
\text { according to the basic competency achievement } \\
\text { indicators }\end{array}$ & 42 & 100 & Well \\
4 & $\begin{array}{l}\text { Make instruments based on the grid that has been } \\
\text { made. }\end{array}$ & 27 & 64,28 & Enough \\
$\begin{array}{l}\text { Analyzing the quality of the assessment instrument by } \\
\text { referring to the instrument requirements and using the } \\
\text { reference criteria } \\
\text { Make plans for assessing student attitudes through self- } \\
\text { assessment of students through timeliness in collecting } \\
\text { the assignments given }\end{array}$ & 42 & 83,33 & Well
\end{tabular}


7 Analyze the quality of the assessment instrument by referring to the instrument requirements

8 Set the weight of the assessment according to current conditions

$9 \quad$ Establish minimum scoring criteria

\begin{tabular}{ccc}
42 & 100 & Well \\
31 & 73,8 & Enough \\
42 & 100 & Well \\
\hline
\end{tabular}

\subsection{Implementation of Authentic Assessments}

Table 4. Implementation of Authentic Assessment

\begin{tabular}{|c|c|c|c|c|}
\hline No & $\begin{array}{l}\text { Sub Indicator } \\
\end{array}$ & Score & Percentage & Criteria \\
\hline 10 & $\begin{array}{l}\text { Carry out assessment procedures that have been } \\
\text { made. }\end{array}$ & 42 & 100 & Well \\
\hline 11 & $\begin{array}{l}\text { Guarantee that during online learning, there will be no } \\
\text { cheating during the exam. }\end{array}$ & 26 & 61,9 & Enough \\
\hline 12 & $\begin{array}{l}\text { Checking the results of student work in the form of } \\
\text { making videos of natural disasters based on the } \\
\text { suitability of themes, clarity of images and sound. }\end{array}$ & 42 & 100 & Well \\
\hline 13 & $\begin{array}{l}\text { Follow up, students who have not submitted the } \\
\text { assignment by providing allowance for } 3 \text { days. }\end{array}$ & 23 & 54,76 & Not Good \\
\hline 14 & $\begin{array}{l}\text { Provide retests for students with network limitations. } \\
\text { Assessing student observations related to natural }\end{array}$ & 42 & 100 & Well \\
\hline 15 & $\begin{array}{l}\text { disasters in the area where they live in the form of } \\
\text { project assignments. }\end{array}$ & 34 & 80,95 & Well \\
\hline 16 & $\begin{array}{l}\text { Assessing students understanding of the material } \\
\text { types and distribution characteristics of natural } \\
\text { disaster-prone areas in Indonesia. }\end{array}$ & 42 & 100 & Well \\
\hline 17 & $\begin{array}{l}\text { Assess students project task skills in making plans } \\
\text { for evacuation routes for natural disasters in their area. }\end{array}$ & 42 & 100 & Well \\
\hline 18 & $\begin{array}{l}\text { Assessing students portfolio assignments in making } \\
\text { clippings about natural disaster mitigation. }\end{array}$ & 28 & 66,66 & Enough \\
\hline 19 & $\begin{array}{l}\text { Assess how students read textbooks on disaster } \\
\text { mitigation via submitted videos. }\end{array}$ & 17 & 40,47 & $\begin{array}{l}\text { Less } \\
\text { Good }\end{array}$ \\
\hline 20 & $\begin{array}{l}\text { Conducting enrichment assessments for students who } \\
\text { get complete scores, by deepening disaster } \\
\text { mitigation materials. }\end{array}$ & 39 & 92,85 & Well \\
\hline 21 & $\begin{array}{l}\text { Assess students' knowledge of disaster mitigation } \\
\text { materials with essay questions. }\end{array}$ & 11 & 26,19 & Not Good \\
\hline
\end{tabular}

\subsection{An analysis of authentic assessment results}

Table 5. Analysis of Authentic Assessment Results

\begin{tabular}{clccc}
\hline No & \multicolumn{1}{c}{ Sub Indicator } & Score & Percentage & Criteria \\
\hline 22 & $\begin{array}{l}\text { documenting the value carefully and neatly } \\
\text { feel overwhelmed by authentic assessments during online }\end{array}$ & 21 & 50 & Less Good \\
learning. & 27 & 64,28 & Enough \\
24 & $\begin{array}{l}\text { constrained by time in the assessment because students } \\
\text { sometimes do not submit assignments on time } \\
\text { still confused in making an authentic assessment instrument } \\
\text { suitable for online learning }\end{array}$ & 28 & 100 & Well \\
26 & $\begin{array}{l}\text { difficulty in applying attitude and spiritual assessments } \\
\text { because of not meeting students directly } \\
\text { feeling bored with too many points on the assessment so that } \\
\text { he spent time sorting out these aspects which resulted in not }\end{array}$ & 33 & 72 & Enough \\
27 & 78,57 & Well
\end{tabular}


all of the learning in one day being completely

implemented.

28

not maximal in carrying out and compiling authentic

assessments

29 find it difficult to judge in a spiritual aspect

The results of the assessment are returned Enough to students as feedback

32

42

26

100

61,9

Well

Well

Well

From the table results show that geography teacher who numbered 42 in the District in Provice the Lampung has been good at making plans penila he $\mathrm{n}$ authentically integrated manner deng 's referring to the syllabus and lesson plans. Develop criteria for achieving basic competencies as a basis for assessment. The basic competencies developed are analyzing the types and management of natural disasters through education, local wisdom, and the use of modern technology, as well as making sketches, plans and / or maps of potential disasters in the local area as well as disaster mitigation strategies based on maps. Geography teachers must also adapt to the characteristics of disasters that occur around students' environments. Determine assessment techniques and instruments according to the basic competency achievement indicators. Analyzing the quality of the assessment instrument by referring to the instrument requirements and using the reference criteria. Make plans for assessing student attitudes through student self-assessment through timeliness in collecting the assignments given. Assign the weight of the assessment according tothe current conditions. Establish minimum scoring criteria. Enough in $\mathrm{m}$ arouses instruments based right grilles that have been made, analysis quality assessment instruments with reference to the requirements of the instrument. Rubric is a scoring benchmark used in subjective assessment in the form of an explicit description of certain performance characteristics in a scale range. From these results it can be said that the authentic assessment planning carried out by geography teachers for disaster mitigation education material, is mostly in the good category.

For the implementation of authentic assessment, geography teachers are good at carrying out assessment activities using the assessment procedures that have been made. It is well in examining the results of student work in the form of making videos of natural disasters based on the suitability of themes, clarity of images and sounds. Both in give re-examination for students to network availability. This is done so that all students are getting value, because not all child's place of residence has awarded supplementary penuh. Test Internet network via whatsapp. Well assessment observations of student-related natural disasters in the region where he lives in the form of project tasks. Well assessment students' understanding of the material types and distribution characteristics of natural disaster-prone areas in Indonesia. Good in assessing student project task skills in making plans for evacuation routes for natural Disasters in their area. Good in conducting enrichment assessments for students who get complete scores, by deepening the material for disaster mitigation. It is enough to guarantee that during online learning, there will be no cheating during exams. Enough in Assessing students' portfolio assignments in making clippings about natural disaster mitigation. Less good in following up on students who do not collect duties by way of giving leeway time for 3 days or less anomalous both in m enilai how students read the textbook on disaster mitigation through the videos submitted. Not good in assessing students' knowledge about disaster mitigation material with essay questions, because teachers conduct assessments mostly using written assessments in the form of multiple choices for the domain of knowledge, few teachers use essay tests, because it can burden students in using the internet and takes a long time in do it. Overall the implementation of authentic assessments by geography teachers was in the good category. 
The results of the authentic assessment of the geography teacher, namely, feeling bored with points on too many assessments so that they spent time sorting out these aspects which resulted in not all of the learning in one day being completely carried out [5] Both in less than optimal in carrying out and compiling authentic assessments. Not good at documenting values carefully and neatly. It is enough to feel overwhelmed by authentic assessments during online learning. It is enough to be confused about making an authentic assessment instrument suitable for online learning. It is enough that the results of the assessment are returned to students as feedback. Overall the results of the authentic assessment conducted by the geography teacher were in the good category.

\section{References}

[1] Ani, Y. and Harapan, UP.2018. Authentic Assessment in the 2013 Curriculum. March 2014

[2] Darmalaksana, W., Hambali, RYA., Masrur, A. and Ushuluddin, F. 2020. Analysis of Online Learning during the WFH Pandemic Covid-19 as a Challenge for 21st Century Digital Leaders.

[3] Aisa, A. and Lisvita, L. 2020. Education and Management Studies Use of Information Technology in Online Learning during the Covid Period. vol. 3, no. 4

[4] Sutama, GA. and Sandy, P. Management of Authentic Assessment Curriculum. pp. 105-114.

[5] Kamiludin, K. and Suryaman, M. 2017. Problems in the Implementation of 2013 Curriculum Learning Assessment, vol. 5, no. 1, pp. 58-67. 